\title{
Evaluation of tsunami evacuation planning of the primary school student in Padang
}

\author{
Yosritzal $^{1,{ }^{*}, \text { Badrul Mustafa Kemal }}{ }^{1}$, Mahdhivan Syafwan ${ }^{2}$, Junaidi $^{1}$, Hasdi Putra $^{3}$, Patra \\ Rina Dewi ${ }^{4}$, and Ika Aksellia ${ }^{5}$ \\ ${ }^{1}$ Department of Civil Engineering, Universitas Andalas, Padang, Indonesia \\ ${ }^{2}$ Department of Mathematics, Universitas Andalas, Padang, Indonesia \\ ${ }^{3}$ Department of Information System, Universitas Andalas, Padang, Indonesia \\ ${ }^{4}$ Tsunami Alert Community (Kogami), Padang, Indonesia. \\ ${ }^{5}$ Master of Civil Engineering Program, Universitas Andalas, Padang, Indonesia
}

\begin{abstract}
This paper presents an evaluation of the tsunami evacuation of elementary school children in Padang. The objective of the study is to evaluate the evacuation planning using an observation data from an evacuation Experiment initiated by the Padang Regional Disaster Management Agency (BPBD Padang). In this study, the chosen evacuation destination was evaluated based on the available evacuation time, the evacuation methods, walking speed of the students in a group and the provided tools in the classroom for evacuation as in the guidelines of tsunami evacuation for schools in Hawaii.
\end{abstract}

\section{Introduction}

Since the earthquake and tsunami stroke in Aceh in 2004, many cities on the west coast of Sumatera are frightening of the most anticipated earthquake and tsunami at the Megathrust near Mentawai Island. Padang is one of the cities on the west coast of Sumatera and very close to the Megathrust. Yosritzal and team [1] predict that the most dangerous epicenter of the tsunami-generating earthquake to Padang is near Mentawai Island. The first tsunami wave will reach the coastal line of Padang approximately in 37.1 minutes.

The type of evacuation plan in Padang has been evaluated by Kemal et al. (2017). Based on the prediction in [1], Kemal and team conclude that the evacuation should be made either horizontally or vertically depend on the location of the evacuee [2]. Horizontal evacuation is evacuation from the prone area to the safe area at a hilly land whilst vertical evacuation is evacuation to the nearest three floors or more building. Horizontal evacuation is recommended to people who are at a location farther than $1.5 \mathrm{~km}$ from the hilly land. They should find and evacuate themselves to three floors building at a minimum.

About 3-4 km from the coast, the terrain of Padang city is almost flat with an elevation lower than $5 \mathrm{~m}$. Nearly a half of the population of Padang are living in this area. The Population and Civil Registry of Padang reported that in 2016 the population of Padang was 914,968 with a population growth of about $4.8 \%$ per year [3]. About $9 \%$ of the

* Corresponding author: yosritzal@eng.unand.ac.id 
population is in the primary schools. Considering the distribution of society and their spreading inland, there are about 41 thousand students are having their school located at the prone area. Primary school students are dependent on their teachers and responsible adults around them. Therefore, an evacuation plan should be carefully designed for them.

The aim of this study is to evaluate an evacuation plan for saving primary school students in vulnerable areas during school hour. The evacuation evaluation consists of preparation, evacuation type, evacuation destination, and evacuation drill. Due to the large and complexity of Padang City, the study area is limited to the North Padang District.

\section{Methodology}

The methodological framework of this study is shown in Fig. 1. Data for this study were collected from various sources such as secondary data from the Padang Regional Disaster Management Agency (BPBD), map from google map, observation of evacuation Experiment and an actual interview with a key person of the evacuation drill. The study was started with the identification of the tsunami-vulnerable primary schools in Padang and its location on the map. A matrix of distance from the primary school to some nearest temporary evacuation sites was then developed. An observation was made during an evacuation experiment planned by BPBD and non-government organization such as Tsunami Alert Community. The effectiveness of evacuation was evaluated based on the evacuation speed and coordination among involved parties. The evacuation plan data was collected from an in-depth interview with BPBD key person. Based on the evacuation distance, evacuation speed, and evacuation plan, the evaluation was taken to predict possibility that the students will arrive safely at the temporary evacuation site (TES) before the tsunami wave reach the coastal line. Based on the result of the evacuation, recommendations were made.

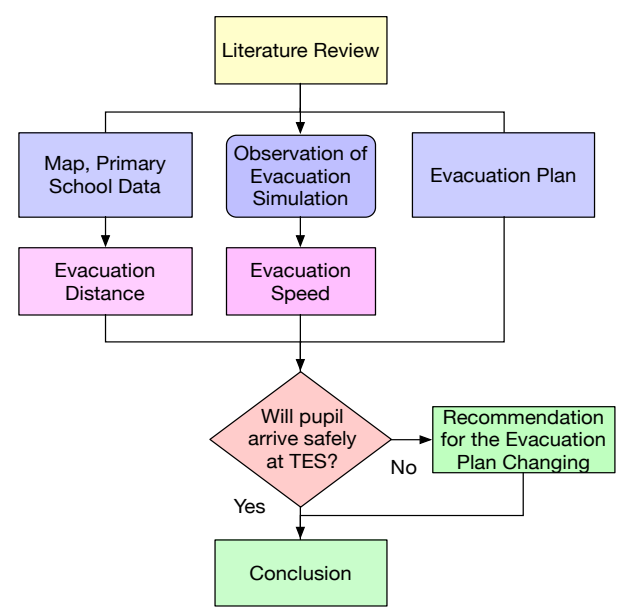

Fig. 1. Methodological framework.

\subsection{Secondary data analysis}

Using tsunami prone areas map and data of the primary schools in Padang, the number and name of the primary schools and quantity of their students in the tsunami-prone area were identified. Data for temporary evacuation sites near the schools were also determined so that the distance from the schools to the sites could be estimated and the route could be 
shown on the map. This data was then being confronted with the observation data of the evacuation drill, to evaluate the effectiveness of the evacuation plan.

\subsection{Evacuation drill observation}

An observation of a tsunami evacuation experiment was made to identify the time needed to reach the TES, evacuation speed and technical issues faced from the analysis. The research was done on 26 April 2018 involving students, teachers, BPBD staffs and nongovernment organization such as Kogami (Tsunami Alert Community).

\section{Results and discussion}

\subsection{Primary schools at the prone area}

Fig. 2 shows the location of the schools and shelters in the North Padang District Map. The map was produced by Franzius-Institut for Hydraulic, Waterways and Coastal Engineering within the "Last-Mile-Evacuation Project." The inundation was estimated based on [4]. Based on Table 1 and Fig. 2, it can be seen whether or not a shelter is reachable within the effective evacuation time before the tsunami wave reaches the coastal line. Natural hazard such as river, fence, and valley could be identified from the map, therefore, could be avoided during estimating distance of evacuation route.

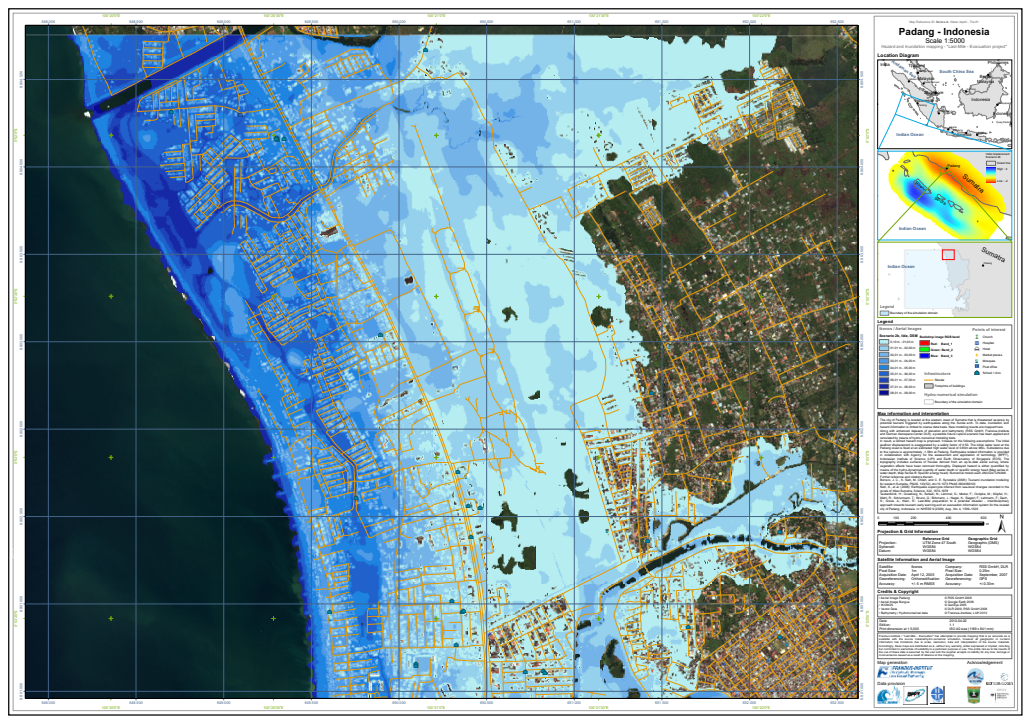

Fig. 2. Location of schools and shelters in North Padang District [5].

Data from the BPBD shows that there is at least 30 number of primary schools at the prone area of the North Padang District with some students and teachers about 7141 people as shown in Table 1. Table 1 also shows the location and the shortest distance from the school to the TES/shelters around the area. Table 1 shows that the maximum distance from any schools to the nearest shelter is $1.48 \mathrm{~km}$. As the propagation time is 37.1 minutes [1], when evacuation is started 5 minutes after the earthquake occurred, students will have 32.1 minutes to be evacuated. The evacuation speed could be estimated based on the observation of an evacuation drill. 
Table 1. Schools' name and distance from the nearest shelter in North Padang District.

\begin{tabular}{|c|c|c|c|c|}
\hline No & Primary school name & $\begin{array}{l}\text { Number of } \\
\text { students and } \\
\text { teachers }\end{array}$ & $\begin{array}{c}\text { The nearest shelter } \\
\text { name }\end{array}$ & $\begin{array}{l}\text { Distance to } \\
\text { the nearest } \\
\text { shelter }(\mathbf{k m})\end{array}$ \\
\hline 1 & SDN Angkasa I & 331 & $\begin{array}{c}\text { TES Masjid Nurul } \\
\text { Haq }\end{array}$ & 1.14 \\
\hline 2 & SDN Angkasa II & 124 & $\begin{array}{c}\text { TES Masjid Nurul } \\
\text { Haq }\end{array}$ & 1.14 \\
\hline 3 & SDN 05 Air Tawar Barat & 194 & $\begin{array}{l}\text { Rector Office } \\
\text { Building of UNP }\end{array}$ & 1.04 \\
\hline 4 & SDN 09 Air Tawar Barat & 169 & $\begin{array}{l}\text { Rector Office } \\
\text { Building of UNP }\end{array}$ & 1.04 \\
\hline 5 & SDN 19 Air Tawar Barat & 147 & $\begin{array}{c}\text { TES Masjid Nurul } \\
\text { Haq }\end{array}$ & 1.48 \\
\hline 6 & SDN 26 Air Tawar Timur & 187 & $\begin{array}{c}\text { TES Masjid Nurul } \\
\text { Haq }\end{array}$ & 0.70 \\
\hline 8 & SDN 16 Air Tawar Timur & 191 & $\begin{array}{l}\text { Rector Office } \\
\text { Building of UNP }\end{array}$ & 0.74 \\
\hline 9 & SDIT Nurul Ikhlas & 266 & $\begin{array}{l}\text { Rector Office } \\
\text { Building of UNP }\end{array}$ & 0.61 \\
\hline 10 & $\begin{array}{l}\text { SDN } 18 \text { Air Tawar } \\
\text { Selatan }\end{array}$ & 143 & $\begin{array}{l}\text { Rector Office } \\
\text { Building of UNP }\end{array}$ & 0.90 \\
\hline 11 & $\begin{array}{l}\text { SDN } 25 \text { Air Tawar } \\
\text { Selatan }\end{array}$ & 103 & Basko Padang & 0.55 \\
\hline 12 & SD Pembangunan & 166 & $\begin{array}{l}\text { Rector Office } \\
\text { Building of UNP }\end{array}$ & 0.35 \\
\hline 13 & SDN 27 Ulak Karang & 794 & TES Ulak Karang & 0.80 \\
\hline 14 & $\begin{array}{l}\text { SDN } 29 \text { Ulak Karang } \\
\text { Utara }\end{array}$ & 218 & TES Ulak Karang & 0.27 \\
\hline 15 & $\begin{array}{l}\text { SDN } 22 \text { Ulak Karang } \\
\text { Utara }\end{array}$ & 122 & TES Ulak Karang & 0.45 \\
\hline 16 & $\begin{array}{l}\text { SDN } 02 \text { Ulak Karang } \\
\text { Selatan }\end{array}$ & 183 & TES Ulak Karang & 0.90 \\
\hline 17 & $\begin{array}{l}\text { SDN } 07 \text { Ulak Karang } \\
\text { Selatan }\end{array}$ & 179 & TES Ulak Karang & 0.90 \\
\hline 18 & $\begin{array}{l}\text { SDN } 08 \text { Ulak Karang } \\
\text { Selatan }\end{array}$ & 160 & TES Ulak Karang & 0.90 \\
\hline 19 & $\begin{array}{l}\text { SDN } 01 \text { Ulak Karang } \\
\text { Selatan }\end{array}$ & 204 & TES Ulak Karang & 0.90 \\
\hline
\end{tabular}




\begin{tabular}{|c|l|c|c|c|}
\hline No & \multicolumn{1}{|c|}{ Primary school name } & $\begin{array}{c}\text { Number of } \\
\text { students and } \\
\text { teachers }\end{array}$ & $\begin{array}{c}\text { The nearest shelter } \\
\text { name }\end{array}$ & $\begin{array}{c}\text { Distance to } \\
\text { the nearest } \\
\text { shelter (km) }\end{array}$ \\
\hline 20 & SDN 06 Kampung Alai & 739 & SD Al-Azhar & 0.85 \\
\hline 21 & $\begin{array}{l}\text { SDN 20 Berok Gunung } \\
\text { Pangilun }\end{array}$ & 168 & SD AL-Azhar & 0.63 \\
\hline 22 & SDN 14 Belanti Barat & 178 & TransMart & 0.48 \\
\hline 23 & SDN 15 Lolong & 116 & SMU 1 Padang & 0.62 \\
\hline 24 & SDN 23 Lolong & 102 & SMK 5 Padang & 0.43 \\
\hline 25 & SDN 11 Lolong & 194 & SMK 5 Padang & 0.07 \\
\hline 26 & SDN 13 Lolong & 165 & SMK 5 Padang & 0.61 \\
\hline 27 & SD Kemala Bhayangkari I & 128 & PU Prof Sumbar & 0.41 \\
\hline 28 & SDN 17 Gunung Pangilun & 161 & Gunung Pangilun & 0.03 \\
\hline 29 & SDN 03 Alai & 916 & PU Prov Sumbar & 1.07 \\
\hline 30 & SD YARI & 212 & Masjid Raya & 0.44 \\
\hline
\end{tabular}

\subsection{Observation of evacuation drill}

On 26 April 2018, the BPBD run some routine tsunami evacuation drills at several schools in Padang, including primary schools, junior high schools, and senior high schools. The evacuation sites for each school might be different depending on the nearest shelter to the schools. The authors have an opportunity to involve and observe the drill especially at one of primary school namely the SDN 15 (State Primary School Number 15) in LolongBelanti, North Padang District. Therefore, the evaluation of the drill will be mainly based on our observation at the school. However, an overview and general information about the evacuation plan for schools will be provided. The evacuation route is shown in Fig. 3.

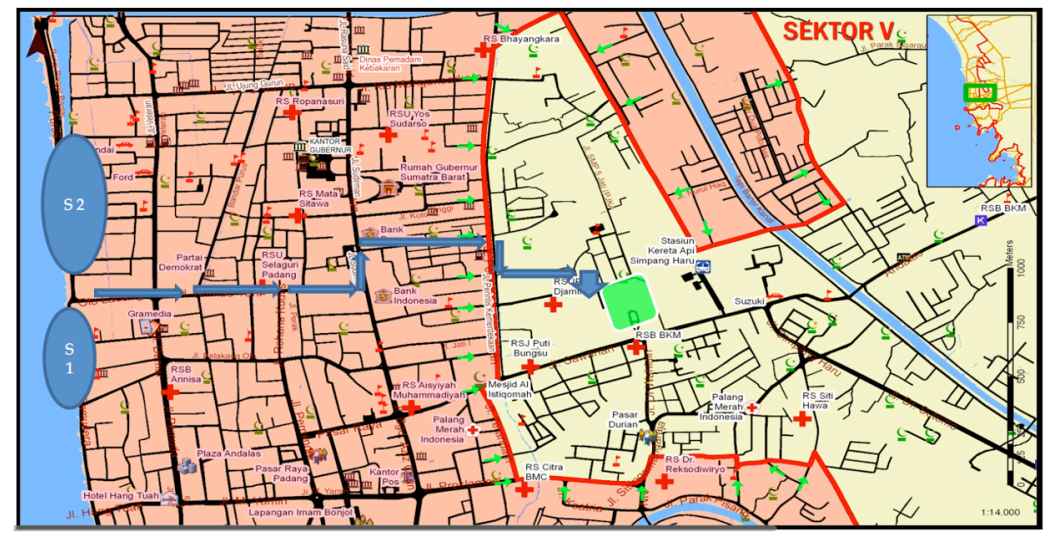

Fig. 3. Evacuation route [6]. 
The evacuation drill at the State Primary School Number 15 in Lolong-Belanti involving at least 96 students and 12 teachers, besides the coaches and NGO's staffs. The drill was started at 10.00 when the first sign of earthquake was switched on, and the first row of the students arrived at the TES at 10.16. The evacuation was started at 10.05. Therefore, the evacuation duration is 11 minutes. As the distance from the primary school to the TES is $0.62 \mathrm{~km}$ and the time spent to travel the route was 11 minutes, then the evacuation speed was $0.93 \mathrm{~m} / \mathrm{second}$ [7].

As told by the officer at the time of the evacuation drill, the scenario for the evacuation experiment was started with a normal condition where students were in their classroom following lessons from their teacher. Suddenly, an earthquake occurs (marked with a siren) and students were ordered to crouch under their tables. After the earthquake stopped (marked with sirens off), students took their bag and used it to cover their head and then went out of the class to a temporary gathering point before proceeding to a shelter. At the brief gathering point, the teacher checked the students condition, and made a report to the school headmaster to get permission for evacuation. Evacuation will start after headmaster's approval. According to the evacuation procedures, parents should be informed to pick their children at the evacuation shelter, when a tsunami potential earthquake is occured.

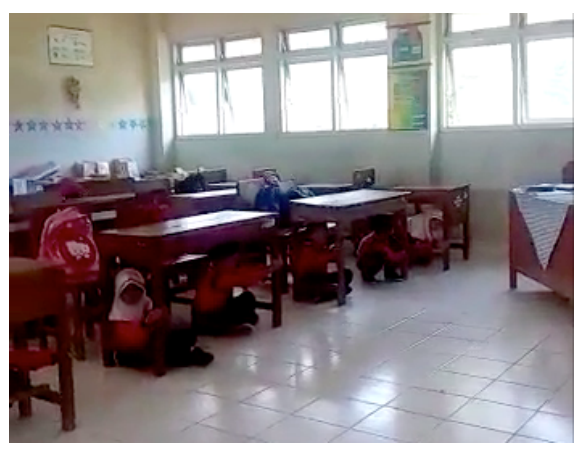

Fig. 4. Students are crouching under the table during the evacuation drill.

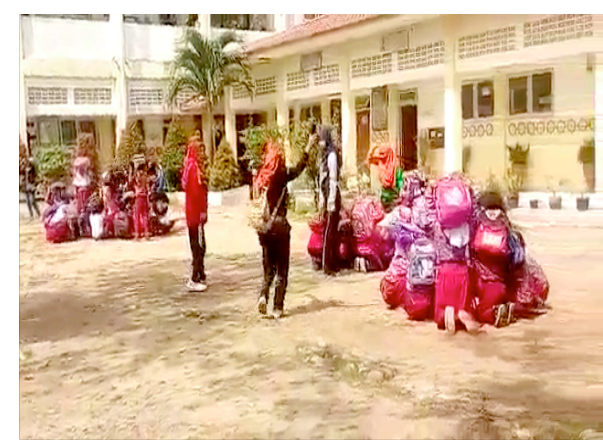

Fig. 5. Students are gathering outside the school before starting the evacuation.

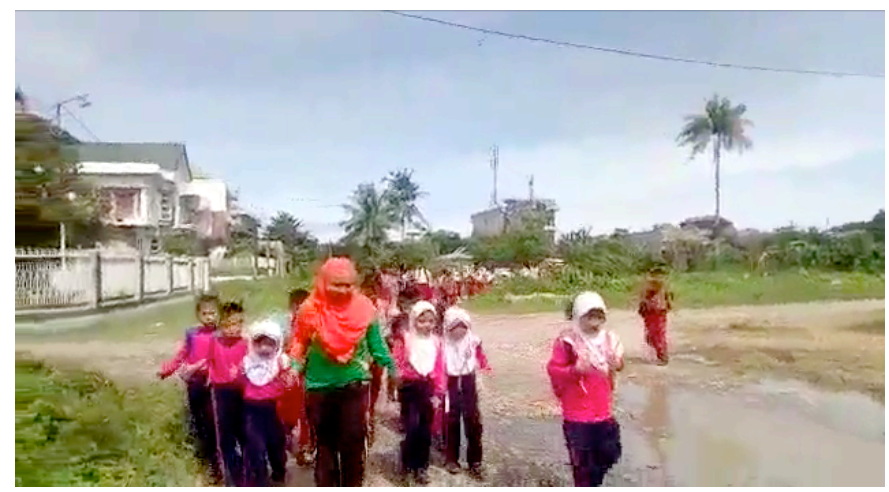

Fig. 6. Students and teachers are walking to the SMU 1 Padang Shelter.

Based on our observation, students understood the instruction and started to crouch under their tables when the sirens as a sign of earthquake on as shown in Fig. 4. When the sirens stop, the students got out from under the table and take their bag, put it over their 
head and marched out of the room to the gathering point. Teachers counted the students number to ensure all of their students were there as shown in Fig. 5. After checking their children, the teachers showed a signal to school headmaster to get permission to evacuate the nearest shelter. After getting permission, teachers led the students to evacuate to a shelter as shown in Fig. 6. The scenario was running well, and all students reaching the safe place within the effective evacuation time.

However, it should be noted that the empowerment is still progressing. There are a lot of things remain to do and be prepared. The evacuation drill has been conducted at several schools to the nearest shelters. However, no backup plan if the nearest shelter being unreachable due to the unpredicted condition. The drill is focused on how the teachers and students being evacuated to a shelter, but some emergency tools have not been prepared. Adopting a checklist from the tsunami evacuation guidelines of schools in Hawaii, Table 2 shows the evaluation of the current evacuation planning for schools in Padang.

Table 2. Evaluation of current condition of the schools evacuation planning in Padang.

\begin{tabular}{|c|l|l|}
\hline No. & \multicolumn{1}{|c|}{ Guideline [8] } & \multicolumn{1}{c|}{ Current condition } \\
\hline 1 & $\begin{array}{l}\text { Teachers, staffs and students } \\
\text { understand the tsunami warning system } \\
\text { and signals in their area and have a } \\
\text { backup alert system for notification. }\end{array}$ & $\begin{array}{l}\text { It is believed that all teacher, staff and students } \\
\text { (especially at target schools), understand the } \\
\text { warning system and signals. Community back up } \\
\text { alert is existed such as from mosques and people } \\
\text { hitting the something (usually power pole) to } \\
\text { make a noisy sound of alert. }\end{array}$ \\
\hline 2 & $\begin{array}{l}\text { All persons understand Natures Own } \\
\text { Warnings (NOW). }\end{array}$ & $\begin{array}{l}\text { Teachers, staffs and students have been told to } \\
\text { protect themselves when feeling a strong } \\
\text { earthquake, cover their head and evacuate to the } \\
\text { evacuation zone after shaking stops. They also } \\
\text { have been told what to do if feel earthquake } \\
\text { shaking for more than 20 seconds, hear rumbling } \\
\text { noise from the ocean, or hear tsunami alert sirens, } \\
\text { the unusual disappearance of water, or unusual } \\
\text { wall of water. All adults are believed to } \\
\text { understand this signals, but students might not } \\
\text { aware of the signals as they are very dependent } \\
\text { on adults help. }\end{array}$ \\
\hline 3 & $\begin{array}{l}\text { The school have a backup school alert } \\
\text { signal that does not depend on power or } \\
\text { technology, i.e. a bullhorn or actual } \\
\text { bell, and periodically use during drills } \\
\text { to familiarize the school with the } \\
\text { signal. }\end{array}$ & $\begin{array}{l}\text { Most schools have a bell and was used during } \\
\text { evacuation drills. }\end{array}$ \\
\hline $\begin{array}{l}\text { Have a tsunami emergency folder in } \\
\text { gach classroom and office, ready to } \\
\text { grab, containing: }\end{array}$ & $\begin{array}{l}\text { Evacuation map, } \\
\text { - Class roster, } \\
\text { - Student medical histories, } \\
\text { - Parent emergency contact } \\
\text { information. }\end{array}$ & $\begin{array}{l}\text { no fin taped on the wall. Parents have been told } \\
\text { tsunami alert is on. }\end{array}$ \\
\hline
\end{tabular}




\begin{tabular}{|c|c|c|}
\hline No. & Guideline [8] & Current condition \\
\hline 5 & $\begin{array}{l}\text { Have all necessary equipment (walkie- } \\
\text { talkies, traffic control vests, flashlights, } \\
\text { etc.) in each classroom and office } \\
\text { where needed. }\end{array}$ & No such equipment in the classroom. \\
\hline 6 & $\begin{array}{l}\text { Ensure that every teacher and staff } \\
\text { member has an updated personal family } \\
\text { emergency plan. }\end{array}$ & $\begin{array}{l}\text { Teacher and staff members have been told to do } \\
\text { so, but not sure if they have done it. }\end{array}$ \\
\hline 7 & $\begin{array}{l}\text { All staff (coaches, substitutes, aides, } \\
\text { etc.) know the evacuation plan. }\end{array}$ & $\begin{array}{l}\text { Teachers and staffs have been told the evacuation } \\
\text { plan. }\end{array}$ \\
\hline 8 & $\begin{array}{l}\text { All parents understand that students } \\
\text { will not be at school but in the safe area } \\
\text { and know where that safe area is. }\end{array}$ & Yes, parents have been told about this. \\
\hline 9 & $\begin{array}{l}\text { Evacuate on foot whenever possible - } \\
\text { avoid using motor vehicles. }\end{array}$ & Yes, evacuation is suggested on foot. \\
\hline 10 & $\begin{array}{l}\text { Have a "Crisis Team" prepared to do a } \\
\text { final sweep of all campus facilities and } \\
\text { shut off utilities prior to finally } \\
\text { securing the campus. }\end{array}$ & $\begin{array}{l}\text { Yes, schools have the crisis team. It is also } \\
\text { written in the standard operating procedures for } \\
\text { evacuation. }\end{array}$ \\
\hline 11 & $\begin{array}{l}\text { Drill using the actual evacuation route } \\
\text { from school to the safe area, and drill } \\
\text { using an alternate backup route. }\end{array}$ & $\begin{array}{l}\text { Yes, the route for the evacuation drill is the } \\
\text { shortest route to the nearest shelter. Other } \\
\text { alternative route has been set but never been } \\
\text { tested. }\end{array}$ \\
\hline 12 & $\begin{array}{l}\text { Carry out "unannounced" drill at } \\
\text { regular intervals. }\end{array}$ & No, to avoid shock. \\
\hline 13 & $\begin{array}{l}\text { Carry out joint tsunamis drills with any } \\
\text { nearby schools. }\end{array}$ & No, each school do their own drill. \\
\hline 14 & $\begin{array}{l}\text { Respond only to an "all clear" from } \\
\text { your own County's CD/ EM agency. }\end{array}$ & Yes. \\
\hline 15 & $\begin{array}{l}\text { Be self-sufficient-do not rely on police, } \\
\text { fire, civil defence or other agencies for } \\
\text { help. }\end{array}$ & $\begin{array}{l}\text { Yes, but the students are too young to rely on } \\
\text { themselves. }\end{array}$ \\
\hline 16 & $\begin{array}{l}\text { Take this very seriously - it could } \\
\text { mean the lives of your students, teacher } \\
\text { and staff. }\end{array}$ & Not all teachers and staffs take the drill seriously. \\
\hline
\end{tabular}

Back to Table 1 in the previous section, the maximum distance from any schools to the nearest shelter is $1.48 \mathrm{~km}$. In the normal condition with evacuation speed, $0.93 \mathrm{~m} / \mathrm{s}$, this distance would be traveled within 26.52 minutes. As the propagation time is 37.1 minutes [1], it is expected that all students will arrive at the nearest shelter before the tsunami wave reach the coastal line of Padang. However, it should be noted that in the real condition, road traffic might not be the same as the evacuation drill condition. Experience from previous earthquakes, traffic jam happened as people started to evacuate using their cars to 
the hills not long after the first shake. So that, the next evacuation drill should anticipate the worst condition where traffic jams occur on every road. If the evacuation is started in 5 minutes after the earthquake, the effective available time to reach the shelter before the first wave reach the coastal line is 32.1 minutes. If the evacuation speed is the same as the drill, 32.1 minutes is long enough to reach the shelter, but in traffic jam condition, the pace might be slower and 32.1 minutes would be insufficient. A backup plan should be initiated for any school that farther than $1.48 \mathrm{~km}$ from the nearest shelter. Another thing should be considered the ratio of demand and capacity of each shelter. Yosritzal and team [9] estimated the demand per capacity ratio of several shelters in Padang. The data showed that some shelters would be overcapacity if no other shelter available nearby.

\section{Conclusions}

An evaluation of the evacuation plan for primary school students in Padang has been investigated. Data showed that the maximum distance from any schools to the nearest shelter is $1.48 \mathrm{~km}$, evacuation speed observed from evacuation drill is $0.93 \mathrm{~m} / \mathrm{s}$. As the propagation time is 37.1 minutes [1], and evacuation is started in 5 minutes after the earthquake, it is expected that all students will reach the shelter before the wave reach the coastal line. However, the evacuation should be started without waiting for information whether a tsunami will occur or not. Comparing the evacuation tools available or provided at schools with the devices expected to be prepared in Guideline of Tsunami Evacuation for School in Hawaii, some of the tools have been prepared, but tools such as evacuation map, the medical record of students, and parent information also need to be arranged. The evacuation drill is now run with planning and needs further study to prepare a back up plan.

This study was funded by the Institute for Research and Community Services of Andalas University on contract number 4/UN.16.17/PP.PGB/LPPM/2018.

\section{References}

1. Yosritzal, B.M. Kemal, F. Siddik F. Proceeding of $1^{\text {st }}$ ASCNI-TECH (2016)

2. B.M. Kemal, Yosritzal, Y.B. Aulia. IJCIET. 8, 10 (2017)

3. BPS, Kota padang dalam angka (Badan Pusat Statistik Kota Padang, Padang, 2017)

4. J.C. Borrero, K. Sieh, M. Chlieh, C.E. Synolakis. PNAS. 103, 52 (2006)

5. Last-Mile Evacuation Project (2010)

6. BPBD, Institutional data (Padang Regional Disaster Management Agency, Padang, 2017)

7. BPBD, Evacuation drill at SDN 15 Lolong (Padang Regional Disaster Management Agency, Padang, 2018)

8. Tsunami evacuation guidelines for schools in Hawaii. Available at: http://www.discovertsunamis.org/pdf/School_Guidelines_for_Tsunami_Conference_Fi nal.pdf (2012)

9. Yosritzal, B.M. Kemal, Y.B. Aulia. IJASEIT (to be published) 